Brit. F. industr. Med., 1966, 23, 230

\title{
Radiochemical Determination of Metallic Mercury Vapour in Air
}

\author{
L. MAGOS \\ From the Toxicology Research Unit, Medical Research Council Laboratories, Carshalton, Surrey
}

A radiochemical method has been developed for the estimation of atmospheric mercury. When air containing mercury is passed through a solution of ${ }^{203} \mathrm{Hg}$-mercuric acetate and $\mathrm{KCl}$, isotope exchange takes place so that the issuing air contains the same concentration of mercury, but labelled and with the same specific activity as the reagent solution. The ${ }^{203} \mathrm{Hg}$ is absorbed on hopcalite and estimated by gamma scintillation counting. The standard deviation of the method is $0.004 \mu \mathrm{g} . \mathrm{Hg} / \mathrm{litre}$ in concentrations up to $0.2 \mu \mathrm{g} . \mathrm{Hg} /$ litre, and is $0.075 \mu \mathrm{g} . \mathrm{Hg} /$ litre in the range $0.2-\mathrm{I} \cdot 2 \mu \mathrm{g} . \mathrm{Hg} /$ litre concentration. The method is simple and can be used for snap or long-run sampling, and with continuous recording.

Mercury in vapour concentrations above $0 . \mathrm{I} \mu \mathrm{g}$. per litre of air (三0.1 mg.Hg/m. ${ }^{3}$ of air) is assumed to present a health hazard if inhaled daily for eight hours (American Conference of Governmental Industrial Hygienists, 1964). The industrial hygienist must therefore have a method for the quantitative estimation of small amounts of mercury vapour in the air. At present, chemical methods (Barnes, 1946; Buckell, I95I), selenium sulphide detectors (Nordlander, 1927; Biggs, 1938), and photoelectric mercury vapour meters (Woodson, 1939; Hanson, 1941; Brooks and Holmes, 1958) are mainly used.

In the method to be described a radioactive isotope of mercury, ${ }^{203} \mathrm{Hg}$, is used. ${ }^{203} \mathrm{Hg}$ emits gamma radiation with a half life of 45 days. Isotopic mercury has been used by Goodman, Irvine, and Horan (1943) who labelled the mercury used in the industrial operation and determined the atmospheric mercury concentration from the activity of the collected air samples. My method, which also detects only metallic mercury vapour, avoids the contamination of the air with radioactive mercury.

The starting point for the search for a radiochemical method was an observation made by Clarkson and Greenwood (1964) in this laboratory. They found that when mercury vapour was passed through a solution of ${ }^{203} \mathrm{Hg}$ - $p$-chloromercuribenzoic acid (PCMB) any mercuric ion contaminating the PCMB was liberated from the solution by the passing air. Further study revealed that when mercury vapour is passed through labelled mercury acetate solutions containing potassium chloride the escaping mercury vapour is labelled to the same

Received for publication November 2, 1965. specific activity as the dissolved mercuric acetate by an exchange reaction. The escaping mercury vapour can therefore be measured by gamma scintillation counting after collection on solid absorbent to give an estimate of the mercury concentration in the air passed through the solution.

\section{Materials and Methods}

Solutions Mercuric acetate-potassium chloride reagent: $2.5 \times 10^{-4} \mathrm{M}$ mercuric acetate and $0.25 \mathrm{M}$ potassium chloride in glass distilled water. Weaker solutions were prepared by dilution. The mercuric acetate was labelled with ${ }^{203} \mathrm{Hg}^{++}$solution obtained from the Radiochemical Centre, Amersham. The increase in mercury concentration caused by labelling was always less than $\mathbf{I} \cdot 0 \%$.

Determination of Mercury Concentration in the Solutions Excess penicillamine (Koch-Light Lab. Ltd.) was added to the samples, and the penicillamine not bound to mercury was determined with 5,5-dithiobis-2(2-nitrobenzoic acid) (Clarkson and Magos, 1966).

Radiochemical Measurements 0.5 to $2.0 \mathrm{ml}$. of the solutions were counted in a well-shaped $\mathrm{NaI}$ scintillation detector (Detector N664B) with a scaler (N6roA, Ekco Electronics, Ltd.), having a counting efficiency for ${ }^{203} \mathrm{Hg}$ of $40 \%$ with a background of 600 counts/100 sec. Specific activities were expressed as counts $/$ IOO sec. $/ \mu \mathrm{g} . \mathrm{Hg}$. The activity of mercury absorbed by the absorber was counted by inserting the absorber into the well of the $\mathrm{NaI}$ scintillation detector.

Absorber The absorbers were Polyallomer tubes, $\frac{5}{8} \times 3$ in. $(15.8 \times 76.2 \mathrm{~mm}$.) (Beckman Instruments Inc., Spinco Division) containing activated hopcalite (Hopkins and Williams Ltd., a solid mixture of copper and manganese oxide). Inlet and outlet tubes were 


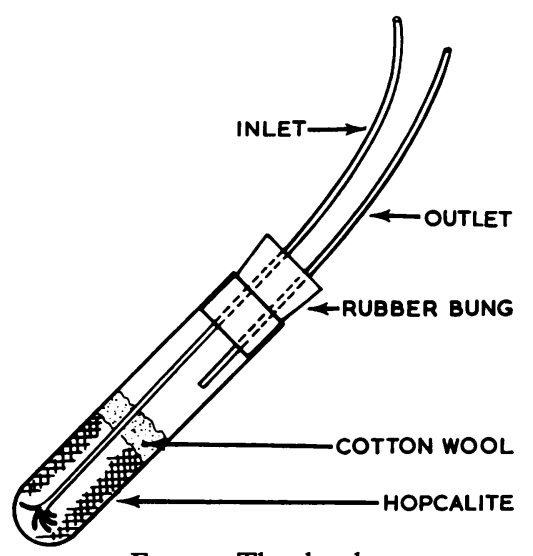

FIG. I. The absorber.

Sterivac polythene cannulae, size 4 , bore $2.0 \mathrm{~mm}$., wall thickness $0.5 \mathrm{~mm}$. (Allen \& Hanbury's Ltd.), led through a rubber bung with a close but a sliding fit. The inlet touched the bottom of the tube and its end was cut and splayed (Fig. I). The absorber was filled by holding the splayed end of the inlet cannula firmly to the bottom of the tube; introducing $3 \mathrm{~g}$. hopcalite; covering with cotton wool; and stoppering the tube by sliding the bung down the inlet cannula.

Saturation of Air with Mercury The saturation system is shown in Figure 2. Compressed air was passed through a Flostat minor (G. A. Platon Ltd.) to regulate the air-flow; a Rotameter (Rotameter Manufacturing Co.) of 5-150 $\mathrm{ml} . / \mathrm{min}$. capacity to measure the air-flow and five 50-ml. and one 250-ml. Quickfit wash bottles, their bottoms covered with metallic mercury; and a coil condenser with 14 coils, every coil containing one droplet of mercury.

In the majority of the experiments saturation was carried out at room temperature. In some experiments air was saturated with mercury at room temperature in the wash bottles and subsequently de-saturated at $0^{\circ} \mathrm{C}$. The coil condenser and a 250-ml. gas washing bottle filled with glass wool were connected in series and immersed in ice. The outgoing air was passed through an inverted Quickfit stirrer guide containing a thermometer which was supported by a pad of glass wool and stoppered. (These modifications are not shown in Fig. 2.)

At $0^{\circ} \mathrm{C}$. the saturated air was assumed to contain $2.24 \mu \mathrm{g} . \mathrm{Hg}$ per litre, the concentration used by Thorpe and Marriott (1957) for calibrating ultraviolet mercury vapour meters. At room temperature mercury concentrations were calculated from the simplified equation:

$$
\mu \mathrm{g} . \mathrm{Hg} / \text { litre }=\frac{200.6 \times(\text { v.p. }) \times 10^{6}}{760 \times(\mathrm{mol} . \mathrm{vol} .)}
$$

where $200.6 \mathrm{I}$ is the atom weight of mercury; v.p. is the vapour pressure of mercury given by the Handbook of Chemistry and Physics (195I) and mol. vol. is the molar volume of mercury at saturation temperature. Changes in atmospheric pressure influence mercury concentration insignificantly so the mole volume was not corrected for them.

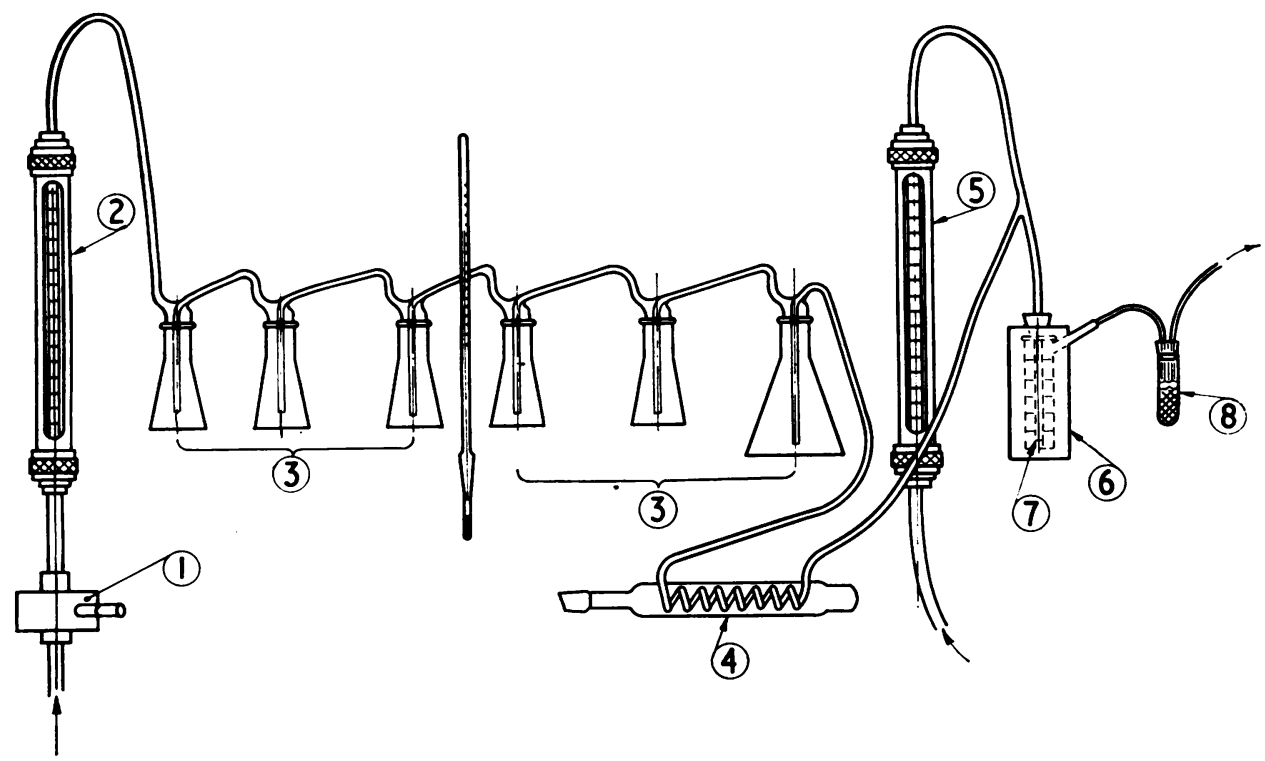

FIG. 2. Details of the system for producing and sampling known concentrations of mercury vapour. (I) Flostat minor to regulate the air-flow through the saturation system; (2) rotameter to measure the volume of the saturated air; (3) Quickfit wash bottles having mercury layer in the bottom; (4) coil condenser having mercury droplets in the coils; (5) rotameter to measure the volume of mercury-free air; (6) lead shield; (7) midget impinger; (8) absorber. 
To obtain lower concentrations the saturated air was mixed with a mercury-free air by a Y piece. Mercuryfree air was taken from the laboratory atmosphere by filtering it through hopcalite attached to the inlet of a Rotameter of $0.5-5.0$ litres/min. capacity and its flowrate was regulated with a Flostat.

Method of Operation The air, with or without added mercury, was sucked through a 30-ml. impinger containing $20 \mathrm{ml}$. of reagent and then through one or more absorbers. The flow rate was I litre/min. except when stated otherwise.

I $\mu$ g. Calibration A plastic syringe with a horizontal tube connected to its eccentric orifice was used for I $\mu$ g. calibration (see Fig. 3). The syringe consists of an outer cylinder, an inner cylinder, and a piston. The inner cylinder can be rotated in the outer cylinder. When the orifices of the inner and outer cylinders communicate, the piston provides the means of adjusting the chamber volume and of filling or emptying the chamber. The volume of the inner cylinder is graduated in ${ }^{\circ} \mathrm{C}$. in such a way that when it is filled with mercurysaturated air to the mark of the room temperature it contains I $\mu \mathrm{g}$. mercury vapour. The syringe was made airtight with silicon stopcock grease (Edward High Vacuum Ltd.). To fill the syringe the horizontal tube was connected with the saturating system and with a water pump giving 75 to $100 \mathrm{ml} / \mathrm{min}$. air-flow. After two to three minutes' flow to ensure saturation in the tube the piston was slowly pulled to the correct mark. The syringe was then closed by turning the inner cylinder. The horizontal tube was disconnected from the saturating system and $0.5 \mathrm{~min}$. later from the water pump. It was connected with the inlet of the midget impinger without interrupting the I litre/min. air-flow. The syringe was opened by turning back the inner

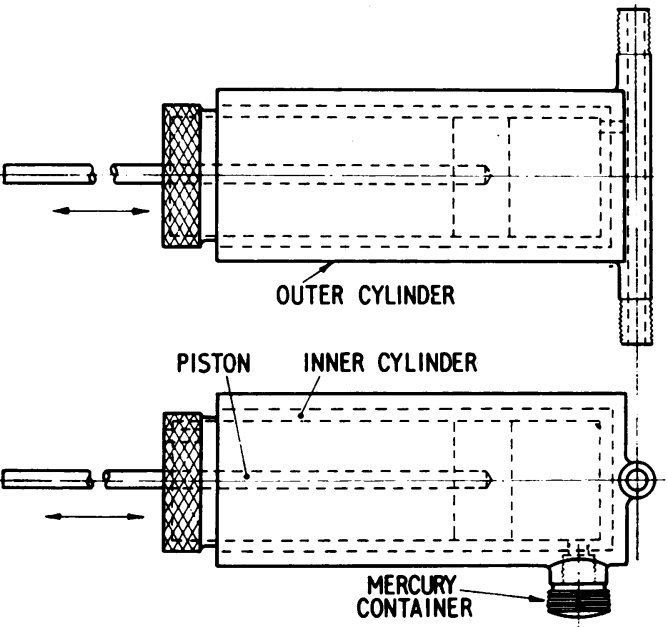

FIG. 3. Plane (upper sketch) and side view (lower sketch) of the $\mathrm{I} \cdot \mathrm{O} \mu \mathrm{g}$. calibrator. cylinder to the original position and the piston was pushed in.

The syringe provided a way of introducing a small quantity of mercury vapour into the air stream in a highly reproducible way without the errors which may attend mixing two air streams. It was therefore useful for standardizing the apparatus and for investigating those factors upon which the exchange reaction depended.

The syringe was also designed so that mercurysaturated air could be produced within it without the use of an external saturating system. The lower part of the syringe (Fig. 3) has a removable attached container, which can be filled with mercury, and the inner cylinder has an aperture which can be lined up with this so that the air in the syringe can become saturated. In 40 to 45 minutes 98 to $99 \%$ saturation was achieved. Before injecting the saturated air the mercury container was always replaced by a solid stopper to avoid the risk of mercury vapour escaping from the container through the grease into the air stream due to the negative pressure.

Disposal of Radioactive Waste The reagent usually contained less than $2 \mu \mathrm{c}$. $/ 20 \mathrm{ml}$. This low radioactivity may be disposed of as normal laboratory waste down a sink. The hopcalite contains much less ${ }^{20}{ }^{3} \mathrm{Hg}$ than the reagent and can be disposed of as normal solid waste.

\section{Results}

Efficiency of the Hopcalite Absorber In each series of tests 8 to Io litres of air containing 12 to $15 \mu \mathrm{g}$. mercury vapour were passed at I litre $/ \mathrm{min}$. through $20 \mathrm{ml}$. reagent $\left(5.0 \times 10^{-6} \mathrm{M}\right.$ ${ }^{203} \mathrm{Hg}$-acetate and $5.0 \times 10^{-3} \mathrm{M}$ potassium chloride, specific activity about 7,800 counts/100 sec./ $\mu$ g.) and then through two hopcalite absorbers in series. The amount of ${ }^{203} \mathrm{Hg}$ removed from the solution was determined from the difference in activity before and after the bubbling period; $99.4 \%$ of the released activity was found in the first absorber and only $0.08 \%$ in the second (mean values in 10 experiments). The recoveries were quantitative within the counting errors. Thus substantially all the ${ }^{203} \mathrm{Hg}$ removed from the solution was absorbed by the first absorber. In this set-up the counting efficiency in the hopcalite was identical with that of the ${ }^{203} \mathrm{Hg}$ in the reagent.

Efficiency of the Exchange Reaction Twenty-ml. samples of reagent $\left(5.0 \times 10^{-5} \mathrm{M}\right.$ ${ }^{203} \mathrm{Hg}$-acetate $+5 \times 10^{-2} \mathrm{M}$ potassium chloride or $2.5 \times \mathrm{IO}^{-4}{ }^{203} \mathrm{Hg}$-acetate $+0.25 \mathrm{M}$ potassium chloride) were tested using the I $\mu \mathrm{g}$. calibrator. In this and every other experiment there was a fiveminute gap between the start of the air-flow and the sampling. The small quantities of metallic mercury released during this initial passage of air through the reagent were washed out and absorbed by a provi- 
sional absorber. After five minutes a sampling absorber was substituted. The sampling lasted three minutes, and in the first 20 seconds I $\mu \mathrm{g}$. mercury vapour was injected into the air stream. Table I shows that the efficiency of the exchange reaction was the same whether $2.5 \times 10^{-5} \mathrm{M}$ or $5.0 \times 10^{-5} \mathrm{M}$ $\mathrm{Hg}$-acetate solution was used. The efficiency in the former case was $97.8 \% \pm 2.33$ (S.D.) and in the latter case $97 \cdot 6 \% \pm 2 \cdot 74$ (S.D.).

Reproducibility was tested on the same reagent solution, five times with mercury-free air and five times with I $\mu \mathrm{g}$. mercury vapour. Table II shows standard deviations of $4.8 \%$ and $3.5 \%$ in two series of experiments. Longer counting times reduced counting errors in the second series. Blank values were only $0.57 \%$ and $0.43 \%$ of the active mercury released, i.e., 0.0019 and $0.0015 \mu \mathrm{g}$. mercury vapour per minute.

Reproducibility was studied over a range of mercury concentrations, using a reagent solution of $2.5 \times 10^{-4} \mathrm{M} \mathrm{Hg}$-acetate $+0.25 \mathrm{M}$ potassium chloride and specific activities from 2,200 to 2,600 counts/100 sec./ug., and a flow rate of I litre/minute. The absorbed activity was corrected for the blank value determined in these tests and for the $97.7 \%$ efficiency of the exchange reaction as found in the previous experiments by using the equation:

$\mu \mathrm{g} . \mathrm{Hg} /$ litre of air $=$

$\left[\frac{\mathrm{r} .025 \text { (count rate in hopcalite) }}{\text { (count rate } / \mu \mathrm{g} . \mathrm{Hg} \text { in reagent) } \times \min .}\right]-0.003$

The results of 33 determinations are shown in Table III. There was no significant systematic error, and the standard deviation was only $\pm 0.0143 \mu \mathrm{g}$./litre in the higher range of concentrations.

In Table IV the results of an experiment are shown with $0.09 \mu \mathrm{g} . \mathrm{Hg} /$ litre air concentration. Without interrupting the sampling process the activity absorbed by the hopcalite was determined at five-minute intervals, and the concentrations were determined from the five-minute differences as well as from the sum of the differences. The standard deviation in the former case was \pm 0.0064 and in
TABLE I

Efficiency of the Exchange Reaction using I $\mu \mathrm{g}$. CALIBRATOR

\begin{tabular}{llll}
$\begin{array}{l}\text { Conc. of } \\
\text { Hg-acetate }\end{array}$ & $\begin{array}{l}\text { No. of } \\
\text { Tests }\end{array}$ & $\begin{array}{l}\text { Efficiency of } \\
\text { the Exchange } \\
(\%)\end{array}$ & $\begin{array}{l}\text { S.D. } \\
(\%)\end{array}$ \\
\hline $2.5 \times 10^{-4}$ & 5 & 97.8 & 2.33 \\
$5.0 \times 10^{-5}$ & 5 & 97.6 & 2.74
\end{tabular}

TABLE II

Reproducibility of the Exchange Reaction using the I $\mu \mathrm{g}$. CALIBRATOR

\begin{tabular}{|c|c|c|c|c|}
\hline \multirow{2}{*}{$\begin{array}{l}\text { Hg-acetate Conc. } \\
\text { in Reagent } \\
(M)\end{array}$} & \multicolumn{4}{|c|}{ Absorbed Activity } \\
\hline & \multicolumn{2}{|c|}{$\begin{array}{l}\text { Without Mercury } \\
\text { Added } \\
\text { (cts/Ioo sec.) }\end{array}$} & \multicolumn{2}{|c|}{$\begin{array}{l}\text { With I ug. } \\
\text { Vapour Added } \\
\text { (cts/100 sec.) }\end{array}$} \\
\hline \multirow[t]{5}{*}{$2.5 \times 10^{-4}$} & & $\begin{array}{l}-2 \\
+18\end{array}$ & & $\begin{array}{l}2,110 \\
2,118\end{array}$ \\
\hline & & +21 & & 2,303 \\
\hline & & $+4 I$ & & 2,228 \\
\hline & & -15 & & 2,342 \\
\hline & Mean & +13 & $\begin{array}{l}\text { Mean } \\
\text { S.D. } \pm\end{array}$ & $\begin{array}{l}2,220 \\
4.75 \%\end{array}$ \\
\hline & \multicolumn{2}{|c|}{$(\mathrm{cts} / 300 \mathrm{sec})}$. & \multicolumn{2}{|c|}{$(c t s / 300 \mathrm{sec})}$. \\
\hline \multirow[t]{2}{*}{$5 \times 10^{-5}$} & & $\begin{array}{r}+124 \\
-\quad 44 \\
+122 \\
+\quad 67 \\
-\quad 58\end{array}$ & \multicolumn{2}{|c|}{$\begin{array}{r}9,313 \\
9,536 \\
9,422 \\
10,038\end{array}$} \\
\hline & Mean & +42 & $\begin{array}{l}\text { Mean } \\
\text { S.D. } \pm\end{array}$ & $\begin{array}{l}9,660 \\
3.45 \%\end{array}$ \\
\hline
\end{tabular}

the latter case $\pm 0.00 \mathrm{I}$. In the former case, as the activity of the hopcalite increased, the counting error of one five-minute period nearly trebled, whereas in the latter case the counting error decreased to nearly one-third.

In experiments on the effect of $p \mathrm{H}$, temperature, air-flow, and different air contaminants the I $\mu \mathrm{g}$. calibrator was used and $5 \times 10^{-5} \mathrm{M}$ mercury acetate $+5 \times 10^{-2} \mathrm{M}$ potassium chloride was the reagent.

Effect of pH It was found that if the $p H$ of the reagent, normally 6.2 , was changed to 9.6 with

TABLE III

Comparison of Results Given by the Method with Calculated Mercury Concentrations

\begin{tabular}{lllll}
$\begin{array}{l}\text { No. of } \\
\text { Samples }\end{array}$ & $\begin{array}{l}\text { Sampling } \\
\text { Time } \\
(\text { min. })\end{array}$ & $\begin{array}{l}\text { Saturation } \\
\text { Temp. } \\
\left({ }^{\circ} \mathrm{C} .\right)\end{array}$ & $\begin{array}{l}\text { Calculated Conc. } \\
(\mu g . H g / l .)\end{array}$ & $\begin{array}{l}\text { Mean } \\
(\text { calc. })-(\text { found }) \\
\text { Conc. }(\mu g . H g / l .)\end{array}$ \\
\hline I4 & 20 or 30 & $0^{\circ}$ & $0.016-0.205$ & -0.0008 \\
I9 & I0, 15 or 20 & ambient & $0.166-1 \cdot 210$ & -0.0033
\end{tabular}


TABLE IV

Continuous Mercury Vapour Determination Near to the M.A.C. Value

\begin{tabular}{|c|c|c|c|c|c|}
\hline $\begin{array}{l}\text { Counting } \\
\text { Started } \\
\text { at } \text { (min.) }\end{array}$ & $\begin{array}{l}\text { Total Activity } \\
\text { in Absorber } \\
\text { (cts/100 sec.) }\end{array}$ & $\begin{array}{l}\text { Activity } \\
\text { Increase/5 min. } \\
\text { (cts/100 sec.) }\end{array}$ & $\begin{array}{l}\text { Calc. Conc. } \\
\text { from 5-min. } \\
\text { Increase } \\
(\mu g . \mathrm{Hg} / l .)\end{array}$ & $\begin{array}{l}\text { Total } \\
\text { Activity } \\
\text { Increase } \\
\text { (cts/100 sec.) }\end{array}$ & $\begin{array}{l}\text { Calc. Conc. } \\
\text { from Total } \\
\text { Activity Increase } \\
(\mu g . H g / l .)\end{array}$ \\
\hline 0 & I,I9I & & & & \\
\hline 5 & 2,269 & $I, 078$ & 0.089 & 1,078 & 0.089 \\
\hline I0 & 3,284 & 1,015 & 0.083 & 2.093 & 0.086 \\
\hline 15 & 4,332 & 1,048 & 0.086 & 3,141 & 0.087 \\
\hline 20 & 5,470 & 1,138 & 0.093 & 4,279 & 0.088 \\
\hline 25 & 6,415 & 945 & 0.077 & 5,224 & 0.086 \\
\hline \multirow[t]{2}{*}{30} & 7,556 & $\mathrm{I}, \mathrm{I} 4 \mathrm{I}$ & 0.094 & 6,365 & 0.087 \\
\hline & & $\begin{array}{l}\text { Avera } \\
\text { S.D. }\end{array}$ & $\begin{array}{c}0.087 \\
\pm 0.0064\end{array}$ & & $\begin{array}{c}0.087 \\
\pm 0.0011\end{array}$ \\
\hline
\end{tabular}

Specific activity of the reagent: 2,420 counts/100 sec./litre/ $\mu \mathrm{g}$; calculated mercury vapour concentration: $0.092 \mu \mathrm{g} . \mathrm{Hg} / \mathrm{litre}$; counting time $100 \mathrm{sec}$.

sodium hydroxide or to $I \cdot 5$ with citric acid the efficiency of the exchange reaction was unaffected.

Effect of Temperature The impinger containing the reagent was immersed in a water-bath at different temperatures. It was found that temperature had no influence on the exchange reaction between $5^{\circ} \mathrm{C}$. and $30^{\circ} \mathrm{C}$., but at $0^{\circ} \mathrm{C}$. the efficiency decreased (Table V).

Effect of Air-Flow Increasing the air-flow from 1.0 to 1.5 litre $/ \mathrm{min}$. had no effect, but decreasing it to 0.5 litre $/ \mathrm{min}$. slightly increased the efficiency (Table V).

TABLE V

EFFect of ENVIRONMENTAL TEMPERATURE AND AIR-FLOW ON THE EXChaNGE OF I $\mu \mathrm{g}$. UNLABELLED Hg VAPOUR TO LABELlED

\begin{tabular}{llll} 
Air-flow (l./min.) & 0.5 & $I \cdot 0$ & $I \cdot 5$ \\
\hline Temp. ( $\left.{ }^{\circ} \mathrm{C}.\right)$ & $\begin{array}{l}\text { Activity Absorbed by Hopcalite } \\
\text { (cts/100 sec.) }\end{array}$ & \\
\hline 30 & \multicolumn{3}{c}{2,830} \\
25 & 2,830 & \\
20 & 2,920 & 2,830 & 2,840 \\
15 & & 2,830 & \\
10 & & 2,840 & \\
5 & & 2,840 & \\
0 & & 2,440 &
\end{tabular}

Effect of Different Air Contaminants Household gas (containing about 10\% carbon monoxide), acetylene, carbon dioxide, and sulphur dioxide were tested by mixing the gases continuously with the air stream. The final concentrations were as follows: household gas, $\mathrm{I} \%$; acetylene, $\mathrm{I} \% ; \mathrm{CO}_{2}$, $2 \% ; \mathrm{SO}_{2}, 0.1 \%$. None of these gases had any effect at these concentrations. The lack of effect of $\mathrm{SO}_{2}$ needed explanation since sodium tetrachloro- mercurate solution can be used as an $\mathrm{SO}_{2}$ absorber (West and Gaeke, 1956). However, West and Gaeke found that the disulphitomercurate complex is most stable when the chloride ion $/ \mathrm{HgCl}_{2}$ ratio is 2:I, and that above this ratio the stability decreases. As in the reagent the chloride to mercury ratio is much higher, the disulphitomercurate complex-if it is formed at all-might be very unstable. This was proved by saturating reagent with $\mathrm{SO}_{2}$ and subsequently passing air. The hopcalite absorbers warmed up due to the absorption of released $\mathrm{SO}_{2}$; and, when the warming up stopped, the $p \mathrm{H}$ and the efficiency of the reagent were normal.

$\mathrm{H}_{2} \mathrm{~S}$ was tested only qualitatively: From a Kipp's apparatus I $\mathrm{ml}$. gas-air mixture was taken and added every minute to the air stream. This resulted in the formation of a black precipitate in the reagent and a rapid decrease in the efficiency of the exchange reaction. This effect was prevented by introducing a midget impinger with $15 \mathrm{ml}$. of $2 \%$ cadmium chloride before the reagent. Cadmium chloride solution or $\mathrm{N} \mathrm{NaOH}$, which can absorb $\mathrm{SO}_{2}, \mathrm{H}_{2} \mathrm{~S}$, and many other gases, does not interfere with the method when it is used to strip the air of contaminants before passing it through the reagent.

High concentrations of air contaminants which react with the hopcalite can exhaust the absorber in prolonged tests. This is indicated by the warming up of the hopcalite or by the rapid increase in the activity of a second hopcalite absorber in series.

Practical Applications of the Method The $\mathrm{Hg}^{203} \mathrm{Hg}$ exchange reaction can be used for snap tests to determine the exposure from short operations; for long-run sampling to determine the mean concentration over a complete cycle of operations or the whole working day; for recording the fluctua- 
tion of the mercury vapour concentration over a period of time; and it can be applied for the determination of mercury vapour liberated from biological samples in the methods described by Jacobs, Yamaguchi, Goldwater, and Gilbert (1960), Jacobs, Goldwater, and Gilbert (I96I), Lindström (1959), and Kudsk (1965), and can also be a substitute for the selenium sulphide test in the method prescribed by the Ministry of Labour Factory Inspectorate (I957). However, the following discussion is limited to the application of the method for determining atmospheric metallic mercury.

By the suitable choice of the specific activity of the reagent and of the counting time the sensitivity of the method can be altered to suit particular requirements over a wide range. The precision is mainly controlled by counting errors in most circumstances.

The choice of reagent mainly depends on the number of samples to be taken. As a result of the exchange reaction the specific activity of the reagent decreases exponentially. The higher the mercury concentration in the reagent, the less this affects the results. Using $2.5 \times 10^{-4} \mathrm{M}$ mercury acetate, three hours' continuous bubbling of $0 . \mathrm{I} \mu \mathrm{g}$. $\mathrm{Hg} /$ litre decreases the specific activity only $3 \%$, whereas using $5 \times 10^{-5} \mathrm{M}$ mercury acetate solution the decrease is $14 \%$.

The following procedures are recommended.

Snap Sampling The reagent is connected with an absorber and the air-flow (I litre/min.) is started. After five minutes the absorber is changed quickly. After any desired period of time this sampling absorber is replaced with another, and the ${ }^{203} \mathrm{Hg}$ in the absorber is estimated. The air concentration is calculated from Equation (2). The specific activity of the reagent and the ${ }^{203} \mathrm{Hg}$ in the absorber need not be estimated on the same day but, if not, corrections for radioactive decay must be made.

Long-run Sampling The procedure is the same

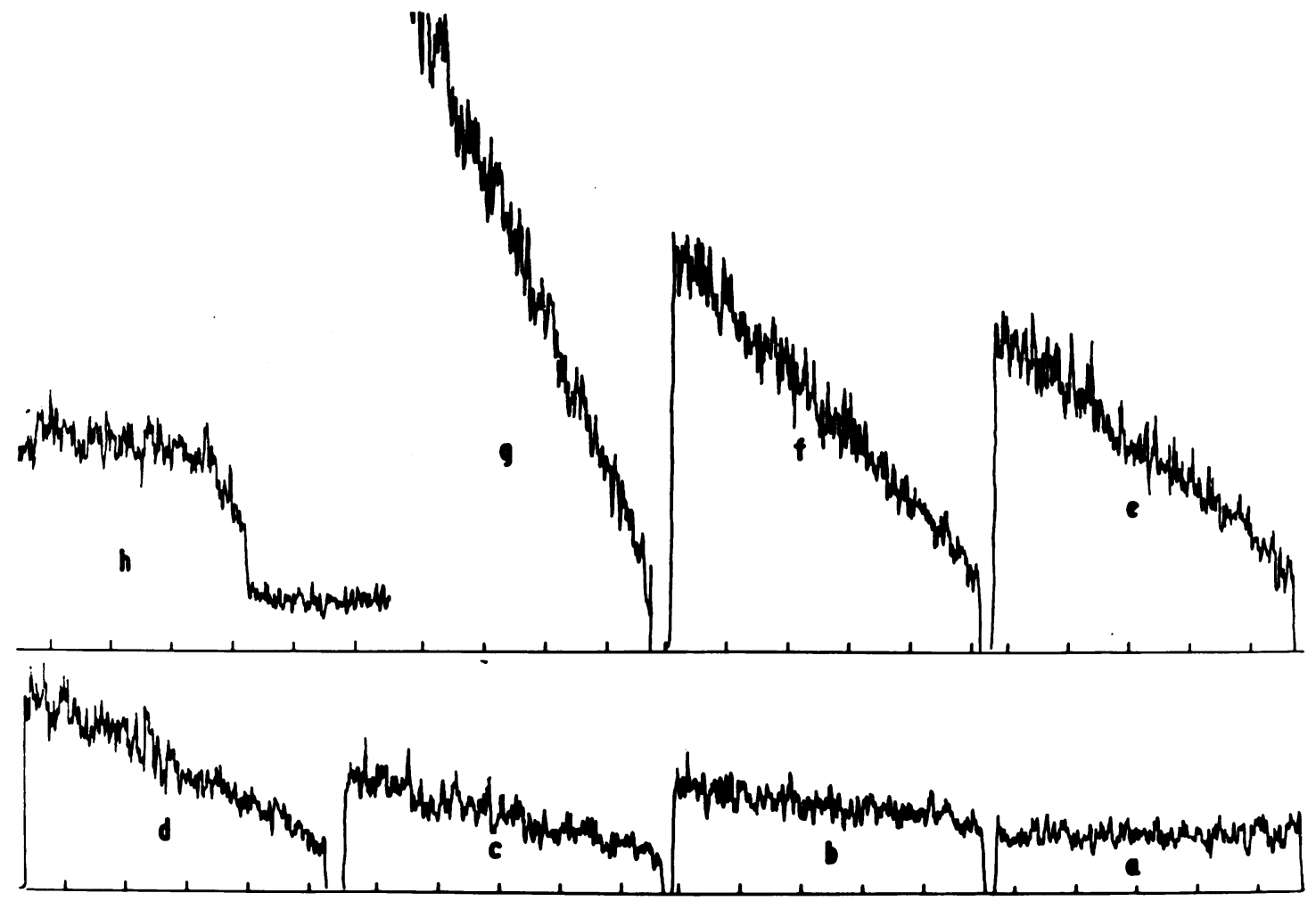

FIG. 4. Records of different concentrations of mercury vapour. The specific activity of the reagent was 2,600 counts/100 sec./ $\mu$ g., the chart speed was $0.5 \mathrm{in} . / \mathrm{min}$., and the scale on the abscissa represents 2 inches.

Vapour concentrations were as follows: $(a)$ blank; $(b) 0.024 \mu \mathrm{g}$./litre; (c) $0.047 \mu \mathrm{g}$./litre; (d) $0.092 \mu \mathrm{g}$. /litre; (e) $0.137 \mu \mathrm{g}$./ litre; $(f) 0.18 \mathrm{I} \mu \mathrm{g}$./litre; $(g) 0.450 \mu \mathrm{g}$./litre; $(h) \mathrm{I} .0 \mu \mathrm{g}$. mercury vapour injected in the air entering the impinger in I5 seconds from the $\mathrm{I} \cdot \mathrm{O} \mu \mathrm{g}$. calibrator. 
as in snap sampling except the calculation. In longrun sampling the loss of specific activity can be high enough to cause a significant error in the calculation. If the ${ }^{203} \mathrm{Hg}$ collected in the hopcalite is up to $10 \%$ of the ${ }^{203} \mathrm{Hg}$ initially in the impinger the average specific activity of mercury should be substituted for the initial specific activity in Equation (2). For example, if the initial specific activity is $\mathrm{r}, 000 \mathrm{cts} / \mathrm{I00}$ sec./ $\mu \mathrm{g}$., and the impinger contains $\mathrm{I}, 000 \mu \mathrm{g} . \mathrm{Hg}$, the total activity initially in the impinger is $10^{6} \mathrm{cts} / 100 \mathrm{sec}$. If $10^{5} \mathrm{cts} / \mathrm{I} 00 \mathrm{sec}$. are collected in the hopcalite, then the impinger finally contains $10^{6}-10^{5}=9 \times 10^{5} \mathrm{cts} / 100$ sec., and the specific activity of the mercury at the end is $9 \times \mathrm{IO}^{5}+$ $1,000=900 \mathrm{cts} / 100 \mathrm{sec}$. The average, $950 \mathrm{cts} / 100$ $\mathrm{sec} . / \mu \mathrm{g} . \mathrm{Hg}$, is therefore put in the bottom of Equation (2). Should the loss from the impinger exceed $10 \%$, the following equation must be used:

$\mu \mathrm{g} . \mathrm{Hg} /$ litre $=$

$\left(\frac{1.025 \times H \times 2.303}{\min .} \times \log _{10} \frac{A_{0}}{A_{0}-A_{r}}\right)-0.003$

where $\mathrm{H}$ is the $\mu \mathrm{g}$. of mercury in the reagent, $\mathrm{A}_{0}$ is the initial ${ }^{203} \mathrm{Hg}$ in the reagent, and $A_{r}$ is the ${ }^{203} \mathrm{Hg}$ released from it and collected in the hopcalite.

Continuous Recording The absorber is placed in the well of the scintillation counter, and this is connected via the scaler with a recorder. Some typical records are shown in Figure 4.

For direct estimations the recorder must be calibrated. This can be done with the I $\mu \mathrm{g}$. calibrator or by recording on the chart the activities of known quantities of ${ }^{203} \mathrm{Hg}$ counted in a test-tube. Once made, such calibrations can be used for any reagent concentrations and specific activities if the setting of the scintillation counter remains unchanged. In this way the ordinate of the chart is converted from activity to weight of mercury, and it is plotted against time on the abscissa. In any given period of time the ascent of the plot in $\mu \mathrm{g}$. divided by the time in minutes gives the concentration of mercury in $\mu \mathrm{g}$./litre.

\section{Discussion}

The method described is simple, more accurate than chemical methods, and flexible. Unlike in estimations by mercury vapour meters the sampling and the determination are not necessarily connected, and, as a result of this, many parallel samples can be taken at the same time. In addition there is nothing equivalent to the drift of the zero point in prolonged test which can disturb estimations with mercury vapour meters. The method requires only a gamma scintillation counter and, for continuous recording, any recorder which can be attached to the scintillation counter. Since analytical methods in industrial hygiene increasingly include the use of radiochemical methods (Keenan, 1965), in a very short time these instruments will be available in any industrial hygiene laboratory.

The author wishes to thank Mr. R. Lock for technical assistance and Mr. R. C. Emery for making the I $\mu \mathrm{g}$. calibrator.

\section{REFERENCES}

American Conference of Governmental Industrial Hygienists (1964). A.M.A. Arch. environm. Hlth, 9, 545.

Barnes, E. C. (1946). f. industr. Hyg., 28, 257.

Biggs, L. R. (1938). Ibid., 20, 161.

Brooks, R. O. R., and Holmes, A. (1958). AERE MED/R 2350, Harwell.

Buckell, M. (195I). Brit. F. industr. Med., 8, 181.

Clarkson, T. W., and Greenwood, M. R. (1964). Personal communication.

and Magos, L. (1966). Biochem. F., in press.

Goodman, C., Irvine, J. W., Jr., and Horan, C. F. (1943). f. industr. Hyg. Toxicol., 25, 275.

Handbook of Chemistry and Physics (I95I). 33rd ed., p. 1937. Chemical Rubber Publishing Co., Cleveland.

Hanson, V. F. (194I). Industr. Engng. Chem., Analyt. ed., 13, II9.

Jacobs, M. B., Goldwater, L. J., and Gilbert, H. (1961). Amer. industr. Hyg. Ass. F., 22, 276.

-, Yamaguchi, S., Goldwater, L. J., and Gilbert, H. (1960). Ibid., 21, 475.

Keenan, R. G. (1965). Arch. environm. Hlth, 10, 583.

Kudsk, F. N. (1965). Scand. F. clin. Lab. Invest., 17, 171.

Lindström, O. (1959). Analyt. Chem., 31, 461.

Ministry of Labour Factory Inspectorate (1957). Methods for the Detection of Toxic Substances in Air. Booklet No. 13 : Mercury and Compounds of Mercury. H.M.S.O., London.

Nordlander, B. W. (1927). Industr. Engng. Chem., 19, 518.

Thorpe, P. E., and Marriott, R. W. (1957). AERE ES/R 2124 , Harwell.

West, P. W., and Gaeke, G. C. (1956). Analyt. Chem., 28, 1816.

Woodson, T. T. (1939). Rev. sci. Instrum., 10, 308. 